\title{
A Study of Growth of Secondary Education in Delhi
}

\author{
Archana Kumari (Corresponding Author) \\ Department of Home Science, Human Development, \\ International College for Girls, IIS University, Jaipur, Rajasthan, India \\ E-mail: archana.kumari@iisuniv.ac.in; 19archana.kumari@gmail.com
}

Received: December 2, 2014 Accepted: January 9, 2015 Published: January 23, 2015

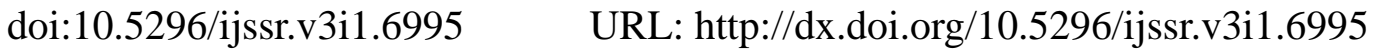

\begin{abstract}
While India has seen a rapid expansion in secondary education, there has been a drift of demand towards private schooling with a large number of parents choosing this in preference to government schools. The present study made an attempt to analyze the pattern of growth of secondary education in Delhi, using data from SEMIS and Directorate of Education. For in depth study primary data was also collected from senior secondary schools of Delhi. The analysis emphasizes the pattern of growth in number of schools and participation in secondary and senior secondary level under different management and the factors affecting the shift in demand towards private schools in Delhi. The overarching findings suggest that in Delhi the government schools have basic resources but, private unaided schools have more advanced resources that are academically important, such as better classroom availability, internet connection, science laboratory and variety of books in the library, which are causing the shift in choice of schools. We also see that, within the sample, children in private schools seem to perform better academically, despite better-qualified and more experienced teachers working in government schools.
\end{abstract}

Keywords: private schools, secondary education, enrollment

\section{Introduction}

Expansion of secondary education and improvement of its quality has been the priority of government policies since independence, and it has remained a matter of concern in each different commission and committees set up from time to time and policy document formulated. The University Education Commission (Radhakrishnan Commission 1948-49) pointed out secondary education as the weakest link in our educational machinery and needs urgent reforms. In 1952, Secondary Education Commission known as Mudaliar Commission was appointed to deal with every aspect of secondary education. Later the National Policy of 
Education 1986 recommended the planned expansion of education facilities all over the country and specially widening access to secondary education by setting up new schools in unserved areas. But due to constitutional obligation of universalization of elementary education and emphasis led by international community on 'Education For All' (EFA), elementary stage of education got highest priority in government's policies and programs as well as in financial allocation under all five year plans as compared to secondary education. In the first five year plan, 13 percent of the total plan expenditure on education was allocated to secondary education as compared to 56 percent on elementary education. It gradually declined to 12 percent in tenth five year plan. In eleventh plan again secondary education has got priority and 20 percent of the plan expenditure on education is allotted to this level of education.

However, despite financial constraints, demand for secondary education has risen and is likely to rise because of high transition rate of about $85 \%$ from class VIII to IX creating pressure of additional enrollment of children at secondary level of education. Therefore, while secondary education is not constitutionally compulsory, it is necessary and desirable that access to secondary education is universalized leading to enhanced participation and its quality is improved for all. But the big question facing policymakers and educationists today is how to carry forward this momentum in primary education to the secondary level in the midst of the severe resource crunch facing the government?

Recognizing the importance of secondary education and the need to expand it, the government of India launched a comprehensive centrally assisted programme called, 'Rashtriya Madhyamik Shiksha Abhiyan RMSA', which aims at making good quality secondary education available, accessible and affordable to all young people. Under Twelfth Five Year Plan to achieve the goal of near universal enrollment, with the GER exceeding 90\% by 2017 at secondary level and to raise the GER to 65\% by 2017 at senior secondary level the government of India had increased the public expenditure on secondary education from Rs. 35,806 crore in 2007-08 to Rs. 94,183 crore in 2011-12. The central government expenditure has gone up from 2,578 crore (2007-08) to 13,278 crore in 2011-12, a fivefold increase. The World Bank is also in the process of preparing support to the Government of India's new centrally sponsored scheme for secondary education, Rashtriya Madhyamik Shiksha Abhiyan (RMSA), for an estimated \$ 500 million (World Bank Report, 2011). There is significant private expenditure as well. The average private expenditure on secondary education in private schools is as high as Rs. 893 per month as compared to only Rs. 275 per month in government schools. This difference is primarily due to high tuition fees in private schools.

Achievement at the level of secondary education in terms of expansion of educational institutions and teachers and participation in terms of enrolment in the five decades is quite commendable. The number of secondary and senior secondary institutes has increased from 1,33,492 (2001-02) to 3,41,225 (2012-13). The participation in terms of enrollment of students at secondary level of education has increased from 30.5 (2001-02) million to 54.5 million in (2012-13). So it can be said that the demand of secondary education has been catered through expanding secondary schools over the years. But the question is that how this growing demand has been catered to especially in terms of response of management types. 'A 
significant feature of educational development from 1980s has been the unprecedented growth of private un-aided schools' (Ayyar, 2011). The fiscal constraints faced by governments in India, especially at the state and local level, have meant that the supply of public education, while expanding rapidly, has not kept up with demand. This along with the enhanced income level and consumer choice as a result of 1990s liberalization policy gave further impetus to private un-aided schools' (Sujatha \& Rani, 2011). According to the World Bank (2011), the education sector in India caters to 600 million people up to the age of 30 years. The annual government spending is 30 billion USD, and it still only amounts to $2.8 \%$ of GDP. Already, annual private spending on education is 43.2 billion USD, making it one of the largest capitalized spaces in India.

As far as growth of secondary schools under different management is concerned, the percentage growth of government as well as private unaided secondary schools is almost same i.e around seven percent from 2004-05 to 2012-13 (government secondary schools 31.66 percent (2004-05) to 38.44 percent (2012-13), Private Unaided secondary schools 28.52 percent (2004-05) to $35.06 \%$ percent (2012-13). But the percentage growth of schools at senior secondary level varies remarkably under different management. The percentage of government senior secondary school has increased only by 0.16 percent (36.08 percent (2004-05) to 36.2 percent (2012-13) whereas private unaided senior secondary schools increased by nine percent over the same period of time (31.79 percent (2004-05) to 41.04 percent (2012-13).

Recognizing the potential of the private sector, the government has started making efforts to shift education discourse in favor of private involvement. The government has committed itself to set up 6,000 model senior secondary schools. Of these, 2,500 are to be set up under the public-private partnership (PPP) model.

Advocacy for public-private-partnership in education depends on some crucial assumption that private education can be more efficient and cost-effective than publicly provided education without diluting the quality of education (Kingdon, 1996; Bashir, 1994; Desai et al., 2008; Kingdon, 2010). The strong demand for private school education reflects dissatisfaction with public schools and a view that private schools offer higher-quality education. Perceptions concerning the superiority of private schools have been confirmed by a number of school surveys (Muralidharan \& Kremer, 2007, Tooley \& Dixon, 2007, Desai et al., 2008; Goyal \& Pandey, 2009).

Growth of private unaided schools has taken place at all level of education but most of the researches are confined to the elementary level of education like PROBE 1990, Govinda and Verghese (1993), Bashir (1994).. There is a need to find out the expansion patteren of secondary education which is a key link between education and economic development as it prepares young minds both for higher education and participation in the overall growth process. Its importance has gone up immensely in recent times in view of the rapid scientific and technological changes taking place in the place of work in a liberalized and globalised economy. This present study also has its importance in the context of recently launched centrally sponsored scheme for secondary education by the government of India - Rashtriya 
Madhyamik Shiksha Abhiyan (RMSA) and the goals set for Twelfth Five year plan to achieve near universal enrollment with GER exceeding 90 percent at secondary level and 65 percent at senior secondary level by 2017. The guiding principles of universalizing of secondary education are universal access, equality and social justice. If these values are to be established in the system then all types of schools including government, private aided as well as private unaided schools has to play a very important role in achieving the target of universalization of secondary education. So, an immediate need was felt to study the demand and growth pattern of government and private secondary schools.

\subsection{Method}

The expansion and growth pattern of secondary schools was measured in terms of number of schools under different management and participation was measured in terms of number of children enrolled in secondary and senior secondary schools under different management.

The present study covered all the secondary and senior secondary schools in all the nine districts of Delhi. The data was collected from divergent sources like Directorate of Education, MHRD's Selected Educational Statistics, All India Educational Survey (NCERT), SEMIS data from NUEPA (2008-09) and other published and unpublished data to depict an overall picture of expansion of secondary education for all the nine districts of Delhi. These data was supplemented with the data of Census data, Economics Survey Reports of Delhi, Statistical abstracts of Delhi published annually and periodically. For in-depth study primary data pertaining to the aspects covered in the study was collected from the sample of twelve senior secondary schools (four governments, four governments aided and four private unaided secondary schools) selected from two districts of Delhi, namely west Delhi and North Delhi. From these twelve senior secondary schools, 20 students of classes X and XII (total - 240 students) from each sampled school was selected randomly. The data obtained from secondary and primary sources was analyzed by using the statistics like Average Annual Growth Rate, coefficient of correlation and percentage. The average growth rate was calculated to see the increase in number of secondary and senior secondary schools and participation of students in class IX, X, XI and XII over the years in Delhi.

\section{Overview of Secondary Education in Delhi}

Any planning for Education Sector needs to take this fact also into account that Delhi being an Educational Hub and National Capital attracts students from almost all northern, central, eastern states as well as from a number of other countries. Government of National Capital Territory of Delhi is making efforts to expand and improve education sector to match the requirement of growing population of the Territory as well as students migrated from other parts.

It could be possible with massive increase in investment in Education Sector by the Government for improvement both in qualitative and quantitative terms. Realizing this fact the plan expenditure on education sector in Delhi increased from 8.53 percent in 2007-08 to 9.63 percent in 2011-12. An amount of Rs. 1901 crores is approved for education sector in 2012-13 against the total approved plan outlay of Rs. 15,000 crore (12.67 percent of total 
outlay). The total expenditure (plan and non plan) on education has increased from Rs. 2154.24 crore in 2007-08 to Rs. 4878.95 crore in 2011-12. It clearly indicates the concern of government of National Capital Territory of Delhi to this sector. The literacy rate in Delhi is continuously improving which is the outcome of education sector improvement programmes of the Government. The literacy rate in Delhi has increased from 61.54\% in 1981 to $75.29 \%$ in 1991, 81.67\% in 2001 and 86.34\% in 2011.The massive increase in investment on education sector has resulted in increase of per capita expenditure on education in Delhi from '2077 in 2007-08 to '3492 in 2011-12. Out of the total expenditure on education, the expenditure on secondary education in Delhi is 2619.81 crore in 2007-08.

In Delhi, Middle, Secondary and Senior Secondary education are primarily looked after by Directorate of Education, Government of National Capital Territory (NCT) of Delhi. The NDMC, though mainly concerned with primary education, is also running a selected number of middle, secondary and senior secondary schools in its areas. Besides these, recognized unaided schools are being run in Delhi by registered trusts and societies. These institutions are managed by an individual or a private organization and do not receive a maintenance grant either from a government or local body. The guidelines, which must be fulfilled by a private school to gain recognition by the appropriate authority, are prescribed in Delhi School Education Act, 1973. Apart from these, another set of schools include the Kendriya Vidyalayas (KVs) and the Jawahar Navodaya Vidyalayas (JNV's) which are managed by autonomous organizations under the Ministry of Human Resource Development.

\subsection{Demand and Growth of Secondary Schools in Delhi}

As far as the growth of secondary schools in Delhi is concerned, the number has increased from 414 (2001-01) to 1965 (2012-13). Over the same period of time, the numbers of senior secondary schools has increased from 1164 in 2001-02 to 1518 in 2012-13. According to the Planning Department, Directorate of Education, this is due to the ongoing mergers among the government schools. Schools, which do not satisfy the minimum criteria, are being shut and the students being sent to the school in the vicinity of the closed school.

One of the reasons behind the growth of senior secondary schools is the growing demand of secondary education. Delhi has witnessed an exponential increase in the number of students enrolled in secondary and senior secondary classes in the last decade. The enrollment in Delhi has increased from 3.54 lakh in 2001-02 to 6.44 lakh in 2012-13 at secondary level and 2.20 lakhs in 2001-02 to 5.80 lakh in 2012-13 at senior secondary level. That means the demand of secondary education has almost doubled and to meet that demand the number of secondary and senior secondary schools has also increased from 1578 (2001-02) to 1872 (2010-11). But the question is that how this growing demand over the years has been catered to especially in terms of response of management types.

The growth in number of secondary and senior secondary schools in response to the growing demand shows a great variation under different management. The percentage of government secondary schools has decreased from $45.24 \%$ in $2004-05$ to $40.6 \%$ in $2010-11$ and the percentage of government senior secondary schools has decreased from 56.54 percent in 2004-05 to 53.9 percent in 2010-11. On the other side percentage of private unaided schools 
has been increasing over the years at secondary (48.81 in 2004-05 to 50.8 in 2010-11) as well as at senior secondary level (30.30 in 2004-05 to 33.9 in 2010-11). The average annual growth rate of private unaided senior secondary schools (3.8) is more than three times from the average annual growth rate of government senior secondary school (1.2).

Table 1. Distribution of school by Management type from 2003-04 to 2010-11

\begin{tabular}{ccccccccc}
\hline \multirow{2}{*}{ Year } & \multicolumn{3}{c}{ Secondary Schools } & \multicolumn{3}{c}{ Sr. Secondary schools } \\
\cline { 2 - 8 } & Govt. & PA & PUA & Total & Govt. & PA & PUA & Total \\
\hline $2003-04$ & 198 & 26 & 242 & 466 & 694 & 167 & 351 & 1212 \\
$2004-05$ & 228 & 30 & 246 & 504 & 683 & 159 & 366 & 1208 \\
$2005-06$ & 211 & 29 & 243 & 483 & 716 & 150 & 391 & 1267 \\
$2006-07$ & 192 & 27 & 241 & 460 & 669 & 163 & 405 & 1237 \\
$2007-08$ & 197 & 28 & 240 & 465 & 715 & 165 & 414 & 1303 \\
$2009-10$ & 209 & 28 & 237 & 474 & 742 & 161 & 447 & 1350 \\
$2010-11$ & 207 & 29 & 244 & 480 & 761 & 159 & 472 & 1392 \\
AAGR* & $\mathbf{0 . 6}$ & $\mathbf{1 . 4}$ & $\mathbf{0 . 1}$ & $\mathbf{0 . 4}$ & $\mathbf{1 . 2}$ & $\mathbf{- 0 . 6}$ & $\mathbf{3 . 8}$ & $\mathbf{1 . 7}$ \\
\hline
\end{tabular}

Source: Selected Educational Statistics, from 2003-04 to 2010-11, MHRD, GOI.

*Average Annual Growth Rate

Enrollment in different types (government, private aided and unaided) of school is dependent on a complex interplay of supply and demand. Hence, availability of types of schools is an important instrument for enrollment in these schools which has been used in the literature (Jimenez, Lockheed, \& Paqueo, 1991).Social composition of an area, history, and state policies all play an important role in shaping the availability of different types of school (Desai, 2008). In Delhi at secondary level the average annual growth rate of enrollment is 19 for private unaided schools, which is almost double of the average annual growth rate of enrollment in government school and quadrupled from private aided schools. At senior secondary level, although in all type of schools the enrollment of students has increased but, in private unaided schools the average annual growth rate is highest (51.0), which is more than three times from the average annual growth rate of government school's enrollment (16.1) and near about double from the average annual growth rate value (27.0) of private aided school's enrollment. According to Economic survey of Delhi 2012-13, the enrollment share of private sector in total enrollment is 42.71 percent. This depicts the higher demand for private unaided schools and drifting of demand of government schools. 


\section{Secondary Classes}

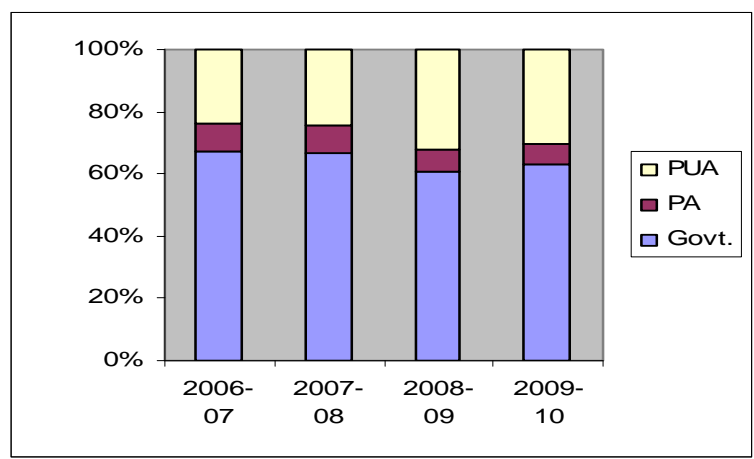

Sr. Secondary Classes

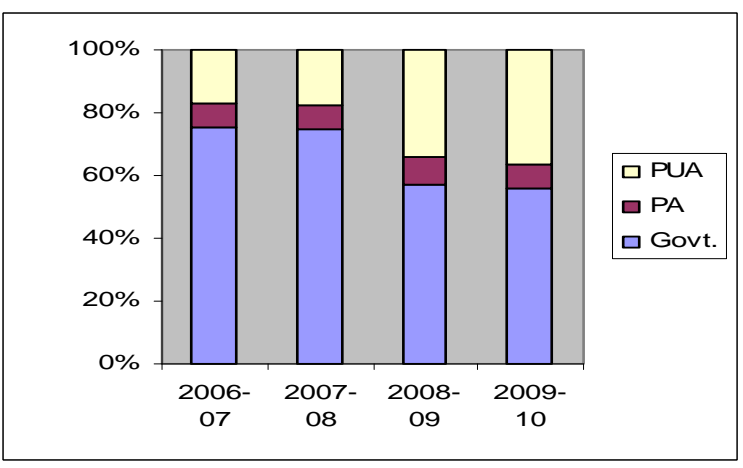

Figure 1. Enrollment in secondary and senior secondary classes from 2006-07 to 2009-10

Table 2. Enrollment in secondary and senior secondary classes from 2006-07 to 2009-10

\begin{tabular}{ccccccc}
\hline & \multicolumn{3}{c}{ Secondary classes } & \multicolumn{3}{c}{ Senior secondary classes } \\
\cline { 2 - 7 } Year & Govt. & PA & PUA & Govt. & PA & PUA \\
\hline $2006-07$ & 215376 & 28042 & 76376 & 123977 & 12058 & 27986 \\
$2007-08$ & 233007 & 31021 & 85842 & 146434 & 14933 & 34698 \\
$2008-09$ & 281841 & 33949 & 148248 & 199343 & 31043 & 118121 \\
$2009-10$ & 320036 & 34221 & 152963 & 224918 & 31408 & 145394 \\
AAGRs & $\mathbf{1 0 . 4}$ & $\mathbf{5 . 1}$ & $\mathbf{1 9 . 0}$ & $\mathbf{1 6 . 1}$ & $\mathbf{2 7 . 0}$ & $\mathbf{5 1 . 0}$ \\
\hline
\end{tabular}

Source: Directorate of Education, Delhi. 2006-07 to 2009-10.

The in depth study of all nine districts of Delhi shows the same trend of much higher average annual growth in enrollment in private unaided school as compared to government and private aided schools at secondary as well as senior secondary level (Table 3).

Table 3. District wise Average Annual Growth Rate of enrollment (from 2006-07 to 2009-10) for class IX to XII in different types of schools of Delhi

\begin{tabular}{ccccccc}
\hline \multirow{2}{*}{ District } & \multicolumn{3}{c}{ Secondary Classes } & \multicolumn{3}{c}{ Senior Secondary Classes } \\
\cline { 2 - 7 } & Govt. & PA & PUA & Govt. & PA & PUA \\
\hline N-W Delhi & 13 & -2 & 22 & 19 & 30.7 & 64 \\
North Delhi & 6.1 & 5.5 & 9.5 & 12.8 & 22.8 & 35.2 \\
N-E Delhi & 12.3 & 6.4 & 10.2 & 24.1 & 44.2 & 24.8 \\
East Delhi & 12.5 & -2.6 & 37.5 & 12 & 41.3 & 69.8 \\
New Delhi & 11.1 & 3.7 & 32.5 & 12.9 & 10.7 & 44.7 \\
Central Delhi & 0.7 & 4.2 & 44.4 & 24 & 29 & 29 \\
West Delhi & 8.9 & 9.8 & 13.7 & 10.4 & 38.1 & 36 \\
S-W Delhi & 5.1 & -2.1 & 14.6 & 10.8 & 2.01 & 35.3 \\
South Delhi & 13.1 & 43 & 46.3 & 17.3 & 11.7 & 98.1 \\
\hline
\end{tabular}

*Source: SEMIS Data 2008-09, NUEPA, Delhi. 
In a stratified society like India, it is common assumption that social hierarchy exists in accessing education and especially to different types of schools. The extent of participation of socially backward communities in terms of enrolment in government and private un-aided schools from 2006-07 to 2009-10 was examined. The Average annual growth shows that the number of SC, ST and OBC students increased in private un-aided schools (Average annual growth rate is 15.3, 31.6, 27.8 for SC, ST and OBC respectively) in comparison to government schools (Average annual growth rate is -6.7, -23.2, -43.3 for SC, ST and OBC respectively). This shows that the demand for different types of schools among disadvantaged communities follow the same trend as for general community. This is probably due to the ability to pay, increased access, awareness and more importantly they belong to a category of second generation learners.

\subsection{Reasons for Proliferation of Private Un-aided Schools in Delhi}

The immigration of a large number of private schools in Delhi has increased the competition. The reason behind student immigration in Delhi for education is that, most of the private unaided schools of Delhi are well equipped; they provide wide exposure to students and availability of a range of schools for students belonging to different socioeconomic background. When the facilities available in private unaided schools are compared with government secondary schools the private unaided schools of Delhi are found much modernized with computer facilities, libraries and well-equipped laboratories. Many of these schools have managed to match the standards of international schools through their infrastructure, staff and facilities. They employ teachers and professors that are highly qualified and professional so that the students attain the best of education (100\% teachers were trained in 2007-08). They tend to maintain an idealistic teacher-student ratio (33 at secondary and 32 at senior secondary level in 2007-08) so that every student gets individual attention and every query and confusion of theirs is solved as soon as possible. They also provide students with qualified counselors that can help them to select a suitable field along with helping them out of any kind of stress. All these features attract the parents and resulting in increased enrollment in private unaided secondary and senior secondary schools of Delhi.

Table 4. Percentage distribution of schools according to the facilities

\begin{tabular}{cccccccc}
\hline \multirow{2}{*}{ Items } & \multicolumn{5}{c}{ Secondary school } & \multicolumn{3}{c}{ Sr. secondary school } \\
\cline { 3 - 8 } & & Govt. & PA & PUA & Govt. & PA & PUA \\
\hline Pucca school building & 48.2 & 93.1 & 96.7 & 68.7 & 95.8 & 94.8 \\
\hline Library & 95 & 100 & 100 & 93 & 100 & 99 \\
\hline \multirow{2}{*}{ No. of Books } & $500-500$ & 56 & 45 & 21 & 46 & 34 & 14 \\
in Library & $1000-2000$ & 15 & 17 & 12 & 8 & 13 & 9 \\
& $>2000$ & 21 & 31 & 57 & 35 & 44 & 71 \\
\hline \multirow{2}{*}{ No. of computers } & $1-10$. & 72 & 66 & 56 & 48 & 61 & 10 \\
& $10-15$. & 12 & 10 & 20 & 8 & 6 & 8 \\
& $15-20$ & 1 & 7 & 11 & 9 & 5 & 12 \\
& $>20$ & 1 & 3 & 8 & 4 & 10 & 68 \\
\hline
\end{tabular}




\begin{tabular}{cccccccc}
\hline Broadband connection & & 91 & 72 & 80 & 93 & 91 & 95 \\
\hline Facility of drinking water & & 97 & 100 & 100 & 94 & 98 & 99 \\
\hline Availability of toilets & For Boys & 31 & 21 & 10 & 22 & 31 & 16 \\
\hline & For Girls & 63 & 72 & 89 & 66 & 64 & 82 \\
\hline & Combined & 94 & 93 & 99 & 88 & 95 & 98 \\
\hline Playground & & 70 & 79 & 89 & 81 & 82 & 97 \\
\hline Disabled friendly infrastructure & & 83 & 34 & 56 & 83 & 43 & 54 \\
\hline Regular Teacher & & 91.8 & 89.6 & 83.7 & 93.3 & 94.7 & 89.4 \\
\hline
\end{tabular}

Source: SEMIS data for 2008-09, NUEPA, New Delhi.

Better infrastructure facilities help students in retaining themselves in schools and to reduce drop-out at the secondary and senior secondary levels. Correlation was carried out to find out the relationship among infrastructure facilities and results of schools. Positive relationship was found between results of schools in terms of pass percentage of students and infrastructure that the school provides and it was found to be highly significant. In other words it can be said that there has to be a close link of coordination between infrastructure facilities and performance of students.

Table 5. Correlation between Percentage of students Pass out and Infrastructure Facilities

\begin{tabular}{ccc}
\hline & & $\begin{array}{c}\text { Index value of school } \\
\text { infrastructure }\end{array}$ \\
\hline \multirow{2}{*}{\begin{tabular}{c} 
Percentage of students pass out Mean result \begin{tabular}{c} 
of 12 years \\
\cline { 2 - 3 }
\end{tabular} \\
\cline { 2 - 3 }
\end{tabular}} & Pearson Correlation & $.371^{*}$ \\
\hline
\end{tabular}

* Correlation is significant at the 0.01 level (2 tailed).

The other feature which attracts parents towards private unaided school is adequacy of teachers in terms of number, qualification and professional experience. The minimum eligibility for TGT (Trained Graduate Teacher) is graduation degree with and for PGT (Post Graduate Teacher), the minimum eligibility criteria is post graduation with professional degree of Bachelor in Education.

Table 6. Percentage Distribution of Qualification of teachers

\begin{tabular}{lllllll}
\hline & \multicolumn{3}{l}{ Secondary classes } & \multicolumn{3}{l}{ Sr. Sec. classes } \\
\cline { 2 - 7 } Educational Qualification & Govt. & PA & PUA & Govt. & PA & PUA \\
\hline Undergraduate & 0 & 12.3 & 0 & 0 & 0 & 0 \\
Grad. \& Equv. & 35.8 & 61.4 & 63.1 & 3.6 & 0 & 0 \\
PG or Equv. & 58.5 & 26.3 & 35.1 & 70.9 & 71.9 & 81.8 \\
M.Phil or Ph.D. or Equv. & 5.7 & 0 & 1.8 & 25.5 & 28.1 & 18.2 \\
Total & 100 & 100 & 100 & 100 & 100 & 100 \\
\hline
\end{tabular}


Although, it was found that almost all teachers at secondary and senior secondary level are well qualified. In fact, percentage of teachers of secondary classes having qualification more than required (PG or Equivalent) was more in government schools (58.7\%) as compared to private unaided schools (35.1\%). At the level of senior secondary $25.5 \%$ teachers of government schools and $18.2 \%$ teachers of private unaided schools are having M.Phil or Ph.D qualified which is again more than the minimum eligibility criteria for post graduate teachers. As far as teaching experience is concerned $60 \%$ teachers of both secondary and senior secondary classes of government schools are having teaching experience of 20-25 years as compared to private unaided schools in which most of the teachers are having 10 to 15 years of teaching experience.

Table 7. Percentage distribution of teaching experience of teachers

\begin{tabular}{cccccccc}
\hline \multirow{2}{*}{ Teaching experience (in years) } & \multicolumn{3}{c}{ Secondary classes } & \multicolumn{3}{c}{ Sr. Secondary classes } \\
\cline { 2 - 7 } & Govt. & PA & PUA & Govt. & PA & PUA \\
\hline $10-15$. & 23 & 20 & 52 & 24 & 34 & 49 \\
$15-20$. & 10 & 13 & 33 & 5 & 41 & 41 \\
$20-25$. & 60 & 56 & 12 & 60 & 25 & 10 \\
$25-30$ & 7 & 11 & 3 & 11 & 0 & 0 \\
Total & $\mathbf{1 0 0}$ & $\mathbf{1 0 0}$ & $\mathbf{1 0 0}$ & $\mathbf{1 0 0}$ & $\mathbf{1 0 0}$ & $\mathbf{1 0 0}$ \\
\hline
\end{tabular}

But at one hand, where the private unaided schools have separate teachers for all subjects, in government schools because of the shortage of teachers the same teacher teaches one or two subjects. Besides these, teachers of government schools are expected to perform numerous other duties like census data collection, election duty, tree plantation duties, pulse polio duties, ministerial work etc. which cut into teaching time. It was reported by one of the teacher of government school during survey that they spent about one month/year on non-teaching activities. On the other side the teachers of private unaided schools are not obligated to perform these duties. They fully concentrate themselves on teaching and all round development of students.

From the analysis of secondary (official data obtained from Directorate of Education) data it was found in the study that all the teachers in all types of schools are on regular basis but, during in depth study of two districts of Delhi it was observed that the real situation was different from what was analyzed from official data. It was observed while conducting the survey that private unaided schools have appointed teachers on contractual basis and they pay salary lesser than specified in the Delhi Education Act. It was also found that mostly teachers for the subjects of computer education, physical education, music and dance are appointed on contractual basis. But when they were asked about the status of teachers in their school, they say that all teachers are qualified, trained and on regular basis. So the figure shown in official data is different from the facts.

It is not only the facilities of international standards and quality of teachers which attract students to private unaided schools but also the output in terms of pass percentage in board examination which shows relatively poor results in government and private aided schools as 
compared to private unaided schools. The gap in pass percentage of private unaided and government schools has decreased over the years (-37.1 in 2004-05 to +0.28 in 2012-13). The comparative picture of the last eight years results of government and private schools shows a completely different picture. The figure shown below reveals that the gap in pass percentage of government and private schools was very wide (-37.07) in 2005-06, which was bridged over the years.

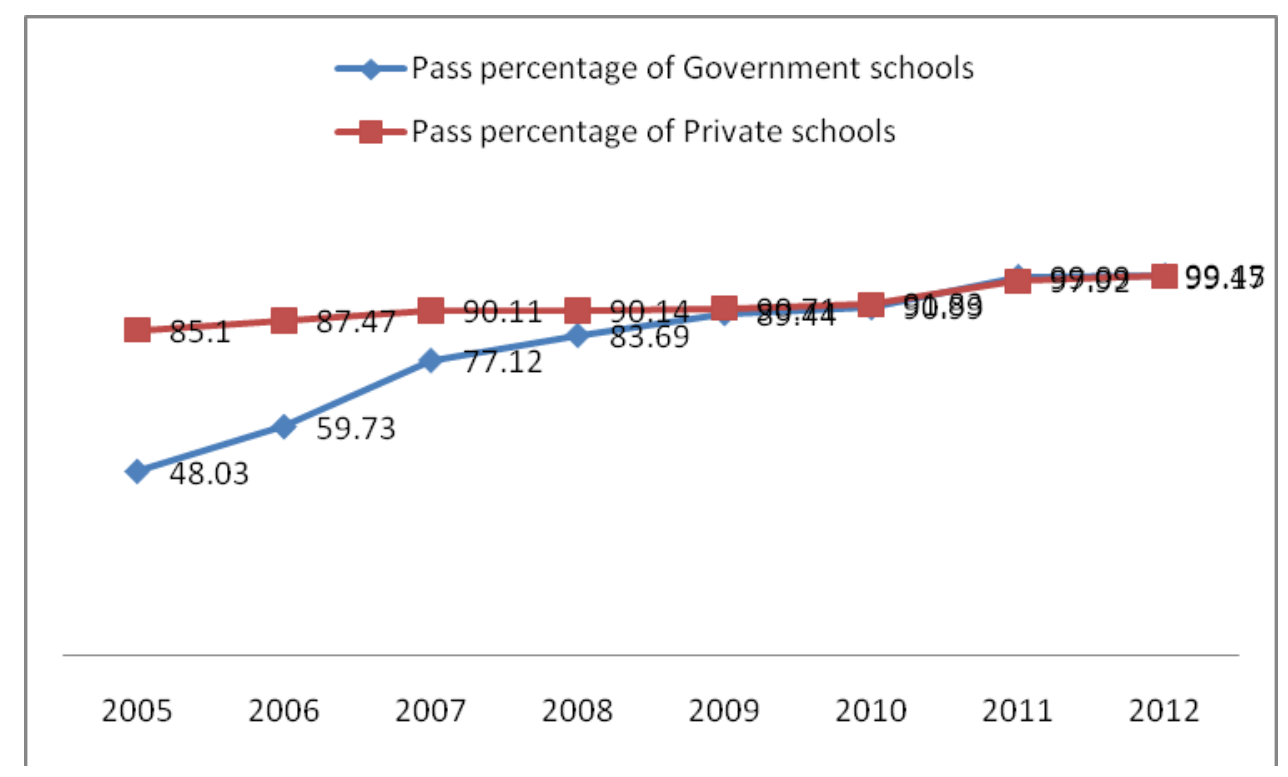

Figure 2. Difference in results (pass \%) of class $\mathrm{X}$ in government and private schools from 2005 to 2012

As per the report of CBSE result of class 12th for 2014, the results of Delhi's government schools were the best in the country among all government schools. The girls recorded an overall pass percentage of 88.52 percent, while boys' pass percentage was 78.27 percent. The overall pass percentage for 2014 - 82.66 percent - recorded a marginal increase of 0.5 percent over last year's 82.10 percent. "The difference between the pass percentage of girls and boys is 10.25 percent.

As per the discussion with officers of Directorate of Education on this achievement, this happened because of the use of comprehensive innovative strategies in government schools by the Director of Education and Education Secretary, Government of Delhi in 2005.The strategy was to generate a consensus that the interests of children had to be kept at the forefront and that the pivotal role of teachers has to be recognized and supported. A web-based system was developed to provide correct information related to different parameters which were necessary for the decision support system for an assessment of reasons for the poor performance. This was aimed at initiating remedial measures in schools. The other reasons for reducing gap in pass percentage of government and private schools are proliferation of low quality private unaided schools, liberal evaluation and moderation of marks, examination on the pattern of Board Examinations and change in the policy of Grade Marks (Narula Manju, 2013). But the findings from the analysis of results of students 
enrolled in sampled schools under different management, taken for in-depth study of two districts has not reflected the same trend. The pass percentage of students of unaided schools was found higher (93.8 percent) as compared to the students of government schools (85.8 percent) in class X public examination. Similarly in class XII board examination pass percentage of students of unaided schools were 95.8 percent in comparison to government (89.2\%) schools.

Parents get attracted from the performance of these reputed school's results and starts assuming that all the private unaided schools are efficient in terms of public examination results and in making future of their children. But simultaneously many low quality private unaided schools are proliferating which is diluting the quality of education and contributing in lowering the average pass percentage of private unaided schools. Although the gap in pass percentage has decreased but, the percentage of students getting first and second rank is still higher in private unaided schools than government and private aided schools. This fall in performance has perhaps paved the way for growth of private unaided schools.

\section{Conclusion}

In the last few decades, in India across the states, educational scenario has undergone significant transformation not only in terms of expansion of educational facilities, but also in terms of types of educational provisioning.

The present study revealed that in Delhi total number of secondary schools under different management has not increased much in last decades but number of senior secondary schools has shown a remarkable growth. Within management wise schools, the average annual growth rate was highest for private unaided senior secondary schools. The choice of parents to send their children in private schools is influenced by many factors like better infrastructure facilities, English medium instruction, better academic performance in results of board examination, subject wise teacher etc. This preference of choice is reflected in the enrollment figure in three different types of schools. The numbers of students enrolled in secondary and senior secondary classes are more in government schools than in unaided schools for the same year but over the years the average annual growth rate of enrollment in private unaided schools are much higher than government schools. That means demand has been drifting from government schools to private unaided schools in spite of high fees charged by these unaided schools.

The reason behind the shift in demand found in the study is advanced resources, which these private unaided schools are having like better classroom availability, internet connection, science laboratory, variety of books in the library etc. It is not like that government school of Delhi does not have basic recourses like other states but the problem is that they are inadequate as per the growing number of students and moreover they are not being used efficiently.

During in depth study of sampled schools of two districts of Delhi, real situation was found different from what was analyzed from official data. As per the official data more than ninety percent of teachers in private unaided schools of Delhi are on regular basis but in the sampled 
schools it was seen that private unaided schools have appointed teachers on contractual basis and they pay salary lesser than specified in the act. Teachers for the subjects of computer education, physical education, music and dance are appointed on contractual basis.

Another fact which was observed that most of the government schools have only one or two computer and that too was kept in the office room and being used for the official work and they were not for the students. As per the SEMIS data in Delhi, a favorable pupil teacher ratio has been maintained in secondary and senior secondary schools i.e. 30 to 33. But during survey more than 40 students were found sitting in the same classroom in private unaided schools. Similarly the official data shows the decrease in gap of pass percentage of government and private unaided schools but the pass percentage in sampled schools did not reflect the same trend. The difference in pass percentage of government and private unaided schools in sampled schools was eight percent at secondary level and 6.6 percent at senior secondary level.

Government of India is envisaging a larger role in the development of secondary education by making the government policies favorable towards private education to meet the excess demand of secondary education. The magnitude of investment required to meet the demand of secondary education may be shared by the private sector if allotment of land is allowed by DDA to the private sector for setting up of new schools at concessional rates with the condition to allocate $25 \%$ of the total intake capacity of the schools under free-ship quota to EWS students. In spite of several efforts to include all the section of the population up to secondary education, large numbers of children are still out of ambit of secondary education. At present GER is 64.2 in Delhi, leaving rest of the children (42.4) out of school at secondary level. MPD-2021 recommends one Sr. Secondary School for every 10,000 population. In view of total number of 1350 Sr. Sec. Schools in Delhi in 2010, 550 new Sr. Sec. Schools are required to be set up during 12th Five Year Plan for the projected population of 190 lakh by 2017. It also suggested in view of problem of land and space, second shift in private school complexes if they fulfill all requirements prescribed by the Directorate of Education.

Much effort is needed to reach the goals set for Twelfth Five year plan to achieve near universal enrollment with GER exceeding 90 percent at secondary level and 65 percent at senior secondary level by 2017. However, there is a need to relook the current licensing and regulatory restrictions for opening of private schools. Time has come to embrace the possibility when government and private schools co-exist, complement each other, as well as compete to attract and retain all children under an equitable and transparent regulatory system.

\section{References}

Ayyar, R. V. (2011), The Policy Implications of the Involvement of Private Actors in Education, Paper presented at ANTRIEP Policy Seminar on The Role of Private Actors in Education: An Opportunity for Innovation or Barrier to Equity, October 19- 21, 2011, by NUEPA, UNESCO \& IIEP, in New Delhi

Bashir, S. (1997). The Cost Effectiveness of Public and Private Schools: Knowledge Gaps, 
New Research Methodologies, and an Application in India. In C. Colclough (Ed.), Marketizing education and health in developing countries: Miracle or mirage. Oxford: IDS Development/Clarendon Press.

Desai, S., Dube A., Vanneman, R., \& Banerji, R. (2008). 'Private Schooling in India - A New Landscape', mimeo NCAER.

Duraisamy, P., James, E., Lane, J., \& Jee-Peng, T. (1997). Is There a Quantity-Quality Tradeoff as Enrollments Increase? Evidence from Tamil Nadu, India. Policy Research Working Paper Series 1768, The World Bank.

Figlio, D. N., \& Stone, J. A. (1997). School Choice and Student Performance. Are Private Schools Really Better? Institute for Research on Poverty Discussion Paper, 1141-97. Madison, WI: University of Wisconsin-Madison.

Govinda, R., \& Varghese, N. V. (1993). Quality of Primary Schooling in India: A Case Study of Madhya Pradesh, International Institute for Educational Planning, Paris, and National Institute of Educational Planning and Administration, New Delhi.

Government of India. (2005). 'Universalisation of Secondary Education', Central Advisory Board of Education, New Delhi, India.

Government of India, Selected Education Statistics. (2004-05, 2005-06, 2006-07, 2007-08, 2008-09, 2009-2010, 2010-2011), Ministry of Human Resource Development, New Delhi.

Government of National Capital Territory of Delhi. Delhi Human Development Report. (2013). New Delhi. Retrieved January 28, 2014, from http://www.delhi.gov.in/wps/wcm/connect/d889268040f180159184bba7591b5f5e/redDHDR 2013.pdf?MOD=AJPERES\&lmod=-579976292\&CACHEID=d889268040f180159184bba75 91b5f5e

Government of India, Planning Commission, First to Twelfth Five Year Plan, (1951-1956 to 2012-2017) Vol. 2, Thematic Issues and Sectoral Programmes, New Delhi, India

Government of India, Ministry of Human Resource Development. (1986). National Policy on Education, New Delhi, India.

Government of India, Ministry of Human Resource Development. (1992). Programme of Action, New Delhi, India.

Government of India. (1966). Education and National Development, Report of the National Commission on Education (1964-66), New Delhi.

Government of India, Delhi Economic Survey (n.d.). Retrieved February 8, 2014, fromhttp://delhi.gov.in/wps/wcm/connect/DoIT_Planning/planning/misc./economic+survey+ of+delhi+2012-13.

Jimenez, E., Lockheed, M. E., \& Paqueo, V. (1991a). The Relative Efficiency of Private and Public Schools in Developing Countries. The World Bank Research Observer, 6(2), 205-218. http://dx.doi.org/10.1093/wbro/6.2.205 


\section{Macrothink}

International Journal of Social Science Research

ISSN 2327-5510

2015, Vol. 3, No. 1

Jimenez, E., Eduardo, L., \& Paqueo, V. (1991b). School Effects and Costs for Private and Public Schools in the Dominican Republic. International Journal of Educational Research, 15(5), 393-410. http://dx.doi.org/10.1016/0883-0355(91)90021-J

Kingdon, G. (1996a). Private Schooling in India: Size, Nature and Equity Effects. Economic and Political Weekly, 31/51, 3306-14.

Kingdon, G. (1996b). The Quality and Efficiency of Public and Private Schools: A Case Study of Urban India. Oxford Bulletin of Economics and Statistics, 58(1), 55-80.

Kingdon, G. (2008). Private and Public Schooling: The Indian Experience. In School Choice International: Exploiting Public-Private Partnerships, edited by R. Chakrabarti and P. Petersen. Cambridge, Mass.: MIT Press.

Muralidharan, K., \& Kremer, M. (2006). Public and private schools in rural India. Working paper, Cambridge, MA: Graduate School of Education, Harvard University. Retrieved from http://www.people.fas.harvard.edu/ muralidh/Public_and_Private_Schools_in_Rural_India

Narula Manju (2013), Report on Growth and Performance of Private Secondary Schools in India: A Study of Madhya Pradesh state, National University of Education Planning and Administration, New Delhi.

Sujatha, K., \& Geetha, R. (2011). Development Of Secondary Education In India: Access, Participation, Delivery Mechanism and Financing, Shipra Publications:New Delhi.

Sujatha, K (2006). Secondary Education in India: Access Demand and Expansion (Part) I, National Institute of Educational Planning and Administration.

Tooley, J., \& Dixon, P. (2007). Private Schooling for Low-income Families: A Census and Comparative Survey in East Delhi, India. International Journal of Educational Development, 27(2), 205-219. http://dx.doi.org/10.1016/j.ijedudev.2006.08.002

World Bank Report (2011). Secondary Education in India: Universalizing Opportunity. Retrieved from http://www.worldbank.org/en/news/feature/2011/09/20/education-in-india

\section{Copyright Disclaimer}

Copyright for this article is retained by the author(s), with first publication rights granted to the journal.

This is an open-access article distributed under the terms and conditions of the Creative Commons Attribution license (http://creativecommons.org/licenses/by/3.0/). 